\title{
Geospatial modelling for groundwater quality mapping: a case study of Rupnagar district, Punjab, India.
}

\author{
S. Sahoo ${ }^{\text {a, } *}$, A. Kaur ${ }^{\text {a }}$, P. Litoria ${ }^{\text {b }}$, B. Pateriya ${ }^{\text {a }}$ \\ ${ }^{a}$ Punjab Remote Sensing Centre, Ludhiana, Punjab, India (www.prsc.gov.in)
}

KEY WORDS: Groundwater Quality, Shallow Aquifer, Water Quality Parameters, IDW, Rupnagar, Punjab.

\begin{abstract}
:
Over period of time, the water usage and management is under stress for various reasons including pollution in both surface and subsurface. The groundwater quality decreases due to the solid waste from urban and industrial nodes, rapid use of insecticides and pesticides in agricultural practices. In this study, ground water quality maps for Rupnagar district of Punjab has been prepared using geospatial interpolation technique through Inverse Distance Weighted (IDW) approach. IDW technique has been used for major ground water quality parameters observed from the field samples like Arsenic, Hardness, pH, Iron, Fluoride, TDS, and Sulphate. To assess the ground water quality of the Rupnagar district, total 280 numbers of samples from various sources of tubewells for both pre and post monsoon have collected. Out of which, 80 to 113 samples found Iron with non potable limits ranging 0.3-1.1mg/l and 0.3$1.02 \mathrm{mg} / \mathrm{l}$ according to BIS standard for both the seasons respectively. Chamkaur Sahib, Rupnagar, Morinda blocks have been found non potable limit of iron in both pre \& post-monsoon. 11 to 52 samples in this region have sulphate with permissible limits in both the season ranging 200-400mg/l and 201-400mg/l. But arsenic had acceptable limit in both the season. Various parameters-wise ground water quality map is generated using the range values of drinking water quality to know the distribution of different parameters and diversification in the concentration of different elements. These maps are very much needful for human being to expand awareness among the people to maintain the Cleanness of water at their highest quality and purity levels to achieve a healthy life.
\end{abstract}

\section{Introduction:}

Groundwater has become an essential commodity in recent decades due to industrialization and unplanned urbanization (Kumari et al., 2012). The occurrence and movement of groundwater in an area is governed by several factors, such as topography, hydro-geomorphology, geology, drainage pattern, land use, climatic conditions and inter relationships among these factors. The quality of groundwater is equally important as its quantity owing to the suitability of water for various purposes (Yidana and Yidana, 2010). It refers variation of groundwater quality in an area is a function of physical and chemical parameters that are greatly influenced by geological formations and anthropogenic activities (Subramani et al., 2005; Vijith and Satheesh, 2007; Nas and Berktay, 2010). The quality of surface water and soil characteristics determines the composition and quality of the groundwater (Atapour, 2012). All the change comes in water quality are not natural whereas man is also responsible for groundwater pollution. These activities are extreme agriculture, power generation; chemical and other industries are main source of groundwater contamination. However, rapid expansion of industries and infrastructure has become hostile, posing a risk to the health and welfare of the people due to release of pollutants from industries and urban sewage (Ntengwe, 2006). The chemical properties of groundwater also depend upon the chemistry of water in the recharge area as well as on the different geochemical processes that are occurring in the subsurface. These geochemical processes are responsible for the seasonal and spatial variations in groundwater chemistry (Matthess, 1982).

The present study, different maps and graphical representations are used to classify and interpret the geochemical data in terms of interpolation map of chemical parameters pollution along with its suitability for drinking purpose only. An appropriate assessment for the suitability of groundwater requires the concentrations of some important parameters like $\mathrm{pH}$, TDS, $\mathrm{Ca}^{2+}, \mathrm{Na}^{+}, \mathrm{Cl}^{-}, \mathrm{HCO}_{3}^{-}$and $\mathrm{SO}_{4}^{2-}$ compared with the guideline values set for potable water (WHO, 1996). Poor quality of water adversely affects the human health and plant growth (WHO, 2004). The importance of water quality in human health has recently attracted a great deal of interest. In developing countries like India, around $80 \%$ of all diseases are directly related to poor drinking water quality and unhygienic conditions (Olajire and Imeokparia, 2001; David et al., 2011; Khadri et al., 2013).

The hydro-geochemical study with GIS reveals the zones where the quality of water is suitable for drinking and agricultural purposes. In the recent era, groundwater quality and risk assessment maps are important as precautionary indicators of potential risk environmental health problems. Geospatial modelling or interpolation technique in GIS is an estimation of $\mathrm{Z}$ values of a surface at an unstapled point based on the known $\mathrm{Z}$ values of surrounding points. Deterministic interpolation techniques create a surface from measured points, based on their extent of similarity [e.g. inverse distance weighted (IDW)]. In this present study, The main objective of this investigation was to identify the spatial variability of groundwater quality parameters using IDW technique for the major physical and chemical parameters of the groundwater samples in the NE district of Punjab, India.

\footnotetext{
* Corresponding author: Sashikant Sahoo, Scientist, Punjab Remote Sensing Centre

Email Address: sksahoo@prsc.gov.in
} 


\section{Study Area:}

Rupnagar district is also known as Ropar district of Punjab, India. It is also known as ancient town of the Indus Valley Civilization.

Location: Rupnagar included in the Patiala division of Punjab falls between latitude $31^{\circ} 24^{\prime}$ and $30^{\circ} 32^{\prime}$ and longitude $76^{\circ} 18^{\prime}$ and $76^{\circ} 55^{\prime}$ (Figure 1). It shares its boundary with SBS Nagar, Mohali and Fatehgarh Sahib District of Punjab. The total area is $1,440 \mathrm{~km}^{2}$ with 684,627 total populations. The density of population is $480 / \mathrm{km}^{2} .82 .19 \%$ is literacy rate in the region. The Satluj River passes close $(2-5 \mathrm{~km})$ to the towns of Nangal, Rupnagar and Anandpur Sahib.

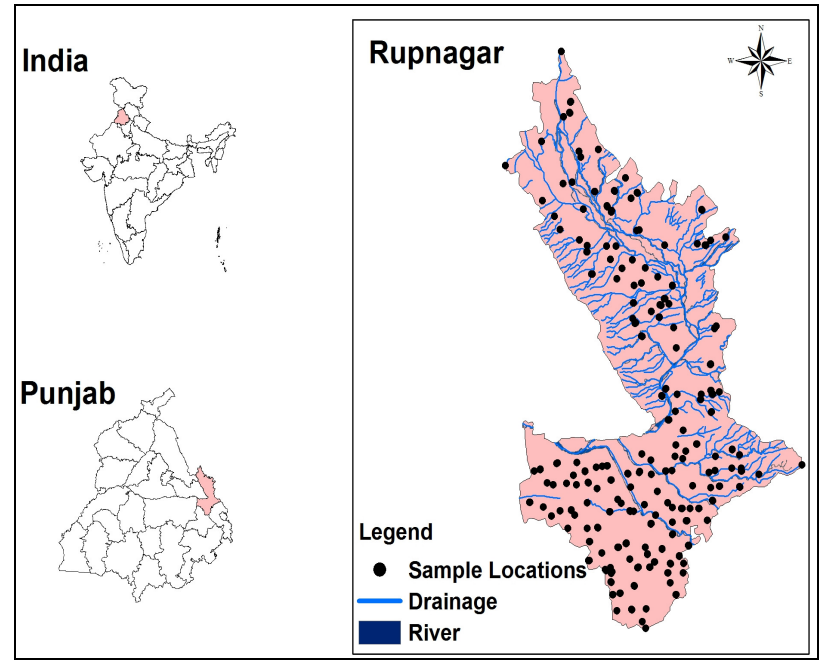

Figure 1. Study Area showing the sample locations of for groundwater quality mapping in Rupnagar District, Punjab, India

Climate: The climate of the district is severe hot and cold during winter and summer seasons. Temperature ranges from minimum $4^{\circ} \mathrm{C}$ in winter and $45^{\circ} \mathrm{C}$ in summer. During monsoon season, average relative humidity is $70 \%$ in the region. About $78 \%$ of the annual rainfall is received during the period from June to September (CGWB, 2007).

Geology \& Geomorphology: The rock formations in the area include river terraces, gravel beds, alluvial fans and calctufa beds of recent origin and conglomerates, sandstones and claystones of Upper Shiwalik (Figure 2). Alluvial fan lies adjacent to the intermontane Valley which become transational zone between alluvial plain and hilly areas. There are two types of soils found in the region which are Reddish Chestnut soil and Tropical arid brown soil. (CGWB, 2007)

\section{Material And Methods:}

Sample Collection: The ground water samples of tubewells were collected from MDWS, Govt. of India for both pre and post monsoon with randomly field checked samples. These tubewells are uniformly scattered all over the region approximately. After sample collection, these samples were analysed using different procedures in the laboratory. In the laboratory, different parameters like Alkalinity, Hardness,

Sulphate, TDS, Flouride and Iron were analysed. Arsenic data were collected from the legacy data of MDWS, Govt. of India.

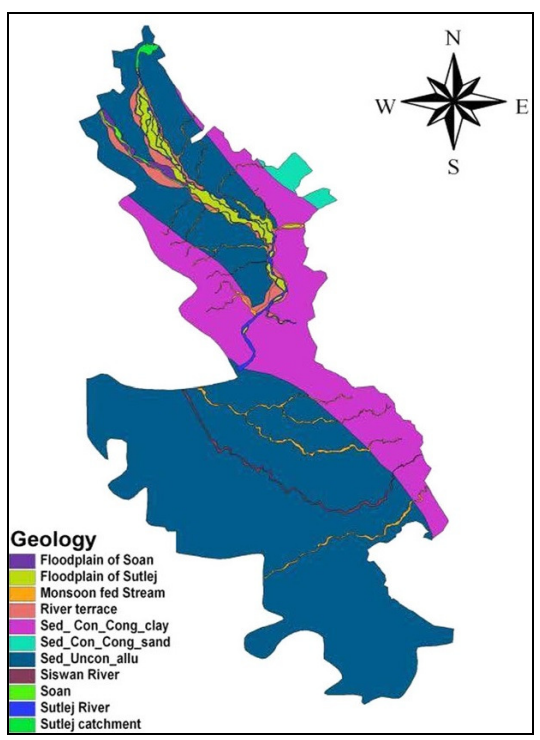

Figure 2. Geological map of study area [Sedimentary (Sed), consolidated (Con), conglomerated (Cong), unconsolidated (Uncon), alluvium (allu)] (Singh, C., et al., 2014)

Data Interpolation: Interpolation is a technique using which ground water quality data can be predicted for unknown points using the ground water quality data of known points. There are so many types of interpolation techniques. In this study, IDW (Inverse Distance Weightage) technique is used for interpolate the data. IDW is a very significant technique for interpolate the data for the groundwater quality studies (NRSC, 2008). It is very usefull for creating contours from data pertaining to points source pollutants caused by industrial and residential activities and converting these contours to polygons. It works on assumptions that ground water quality data of points that are close to one another are more alike than those that are farther apart. It gives more weights to points closest to the prediction point, and the weights diminish as a function of distance.

Table 1. Groundwater quality parameters

\begin{tabular}{lllll}
\hline \multirow{2}{*}{ Parameter } & \multicolumn{2}{c}{ Pre-Monsoon } & \multicolumn{2}{c}{ Post-Monsoon } \\
\cline { 2 - 5 }$(\mathrm{mg} / \mathrm{l})$ & Minimum & Maximum & Minimum & Maximum \\
\hline Arsenic & 0 & 0.02 & 0 & 0.001 \\
\hline Fluoride & 0 & 1.3 & 0 & 1.4 \\
\hline Iron & 0 & 1.02 & 0 & 1.1 \\
\hline Sulphate & 0 & 425 & 0 & 400 \\
\hline pH & 0 & 8.5 & 0 & 8.5 \\
\hline TDS & 0 & 1000 & 0 & 807 \\
\hline Hardness & 0 & 452 & 0 & 498 \\
\hline Alkalinity & 0 & 575 & 0 & 400 \\
\hline
\end{tabular}


Creation of Database: The study is carried out with the help of groundwater samples collection from legacy data of Ministry of Drinking Water Supply and Sanitation (MDWS), Govt. of India and field sample cllection as well. Total 280 nos. of samples collected and tabulated manually from drinking water sources for each habitations of district Rupnagar. Analysis were done in the laboratory by following the drinking water standards as per Bureau of Indian Standards (BIS) guideline (Revised) - IS: 10500:2012 (Table 2). The results were tabulated in an excel worksheet and generated the point data from it.

Table 2. Concentration limits of elements for classification of ground water quality.

\begin{tabular}{|c|c|c|c|c|c|c|}
\hline \multirow[t]{3}{*}{$\begin{array}{l}\text { Para- } \\
\text { meters } \\
(\mathrm{mg} / \mathrm{l})\end{array}$} & \multirow[t]{3}{*}{$\begin{array}{l}\text { Desirabl } \\
\text { e limit } \\
\text { (BIS) }\end{array}$} & \multirow{3}{*}{$\begin{array}{l}\text { Permissi } \\
\text { ble } \\
\text { Limit } \\
\text { (BIS) }\end{array}$} & \multicolumn{2}{|c|}{$\begin{array}{l}\text { samples } \\
\text { exceeding } \\
\text { maximum } \\
\text { permissible } \\
\text { limit (Nos.) }\end{array}$} & \multicolumn{2}{|c|}{$\begin{array}{l}\text { Samples } \\
\text { exceeding } \\
\text { Maximum } \\
\text { Permissible } \\
\text { limit }(\%)\end{array}$} \\
\hline & & & \multicolumn{4}{|c|}{ Season (Monsoon) } \\
\hline & & & Pre & Post & Pre & Post \\
\hline Arsenic & $<0.01$ & $\begin{array}{l}0.01- \\
0.05\end{array}$ & 0 & 0 & 0 & 0 \\
\hline Fluoride & $<1.0$ & $1.0-1.5$ & 0 & 0 & 0 & 0 \\
\hline Iron & $<0.3$ & --- & 65 & 89 & 22.4 & 31.4 \\
\hline Sulphate & $<200$ & $200-400$ & 5 & 3 & 1.72 & 1.06 \\
\hline $\mathrm{pH}$ & $6.5-8.5$ & --- & 0 & 0 & 0 & 0 \\
\hline TDS & $<500$ & $\begin{array}{l}500- \\
2000\end{array}$ & 0 & 0 & 0 & 0 \\
\hline $\begin{array}{l}\text { Total } \\
\text { Hardness }\end{array}$ & $<200$ & $200-600$ & 0 & 0 & 0 & 0 \\
\hline Alkalinity & $<200$ & $200-600$ & 0 & 0 & 0 & 0 \\
\hline
\end{tabular}

(Source: Drinking Water Standards as per BIS Guideline (revised)-IS: 10500-2012)

\section{Result And Discussion:}

Spatial variation of groundwater quality parameters: In this study, IDW geosaptial interpolation modelling was used for calculating the spatial distribution for each groundwater quality parameter for drinking water purposes. The water quality data thus obtained forms the attribute database for the present study. The ground water quality varies from place to place according to different seasons. There is a some valuable change observed in the distribution of water quality parameters value range in two seasons (Pre-Monsoon \& Post-Monsoon) (Table 1). This change is influenced by the surface and subsurface characteristics. The variation among the parameters for each season were discussed below:

Alkalinity: The alkalinity of water is a evaluation of how much acid it can defuse. Total alkalinity is affected by environmental factors; rain, acidic sanitizers, addition of fill water and other product applications can be change the alkalinity overtime. Alkalinity influenced by the calcium carbonate, $\mathrm{CaCo3}$, being leaching from rocks and soils. This process is enhanced if the rocks and soils have been broken up for any reason, such as mining or urban development. Out of 290 samples, 217 samples has the alkalinity with permissible limit in both the seasons. In post monsoon, it lies in $200-400 \mathrm{mg} / \mathrm{l}$ and $200-517 \mathrm{mg} / \mathrm{l} \mathrm{range}$ present in pre-monsoon sample.

Total Hardness $\left(\mathrm{CaCO}_{3}\right)$ : Naturally, total hardness comes from calcium and magnesium mineral salts which are dissolved from the rocks through which rain water flows. Water hardness is the conventional measure of the capability of water to react with soap, hardwater requiring noticeably more soap to produce a lather. 190-200 tubewells has hardness with permissible limits in both the seasons. Its has $200-452 \mathrm{mg} / \mathrm{l}$ in pre monsoon and $200-498 \mathrm{mg} / \mathrm{l}$ in post monsoon respectively. Permissible limit of hardness covers $81.33 \%$ area in pre monsoon and $84.11 \%$ area in post-monsoon from total area of the region.

Flouride: The avalability of Flouride in water is negative and positive. Flourides are vital because they have a specific relation to dental health. In some researches, it is well said that the concentration of $1 \mathrm{mg} / \mathrm{l}$ of Flouride in drinking water decreases tooth decay. Flouride found in very less samples from total. 2-7 samples has the flouride with permissible limits range $1.2-1.3 \mathrm{mg} / \mathrm{l}$ in pre-monsoon and $1-1.4 \mathrm{mg} / \mathrm{l}$ in post-monsoon. In pre-monsoon permissible limit covers $0.09 \%$ area and in post-monsoon it covers $0.08 \%$ area out of total.

Sulphate: The presence of sulphate in the water is natural. The small quantity of it does not create problem but if its concentration is high then it create trouble. The region is affected by sulphate in pre-monsoon more than post-monsoon. Sulphate has permissible limit in both the seasons. 52 samples has permissible limit of sulphate. The concentrated range of the pemrmissible limit is $200-425 \mathrm{mg} / \mathrm{l}$ in pre monsoon and 201 $400 \mathrm{mg} / \mathrm{l}$ in post-monsoon respectively shown in Figure 3. In this figure, it can be found out of all tested samples, only 5 to 6 samples having range above permissible limits in the premonsoon season.

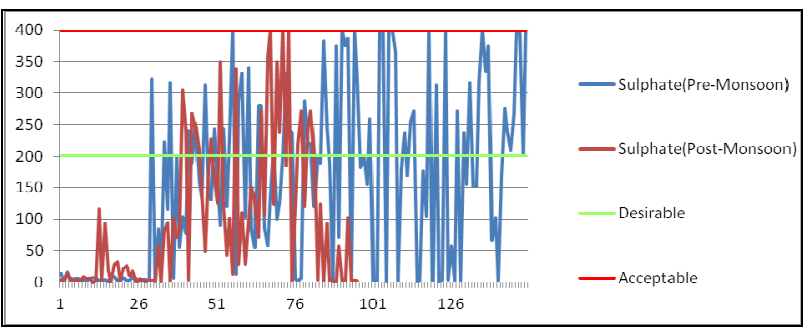

Figure 3. The concentrated range of sulphate for both desirable and accpetable/pemrmissible limit for both pre and post monsoon samples.

Total Dissolved Solids (TDS): Total dissolved solid is an important parameter in drinking water and other water quality standards. Total dissolved solid denotes the various types of minerals present in water in dissolved form. In natural waters, dissolved solids are composed of mainly carbonates, bicarbonates, chlorides, sulphate, phosphate, silica, calcium, magnesium, sodium and potassium. In the study area, majority of the TDS in the study area falls below $1,000 \mathrm{mg} / \mathrm{l}$ and also classified as fresh water (Caroll, 1962). 7-10 tubewells in the region in both the season has above desirable limits but not exceed the desirable limit. The range of TDS in permissible limit is $500-1000 \mathrm{mg} / \mathrm{l}$ in pre-monsoon and $500-807 \mathrm{mg} / \mathrm{l}$ in post monsoon. In pre monsoon, permissible limit covers $0.42 \%$ 
area and in post monsoon it spreads over $0.29 \%$ area out of total area of th study area.

Iron: Iron is generally found in colorless and soluble in groundwater. Unfotunately, organic iron can be quite troublesome. Iron bacteria regularly increases in iron bearing water. As they develop, it may clog pipes and reduce flow rates, which is very dangerous for health perspective. Iron present in both the seasons having non-potable limit in both seasons with range $0.3-1.02 \mathrm{mg} / \mathrm{l}$ in pre-monsoon and $0.3-1.01$ $\mathrm{mg} / \mathrm{l}$ in post-monsoon (Figure 4).

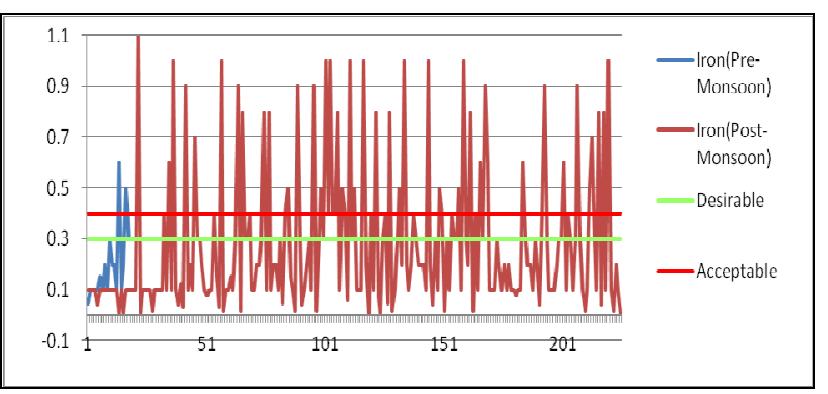

Figure 4. The concentrated range of Iron for both desirable and accpetable/pemrmissible limit for both pre and post monsoon samples.

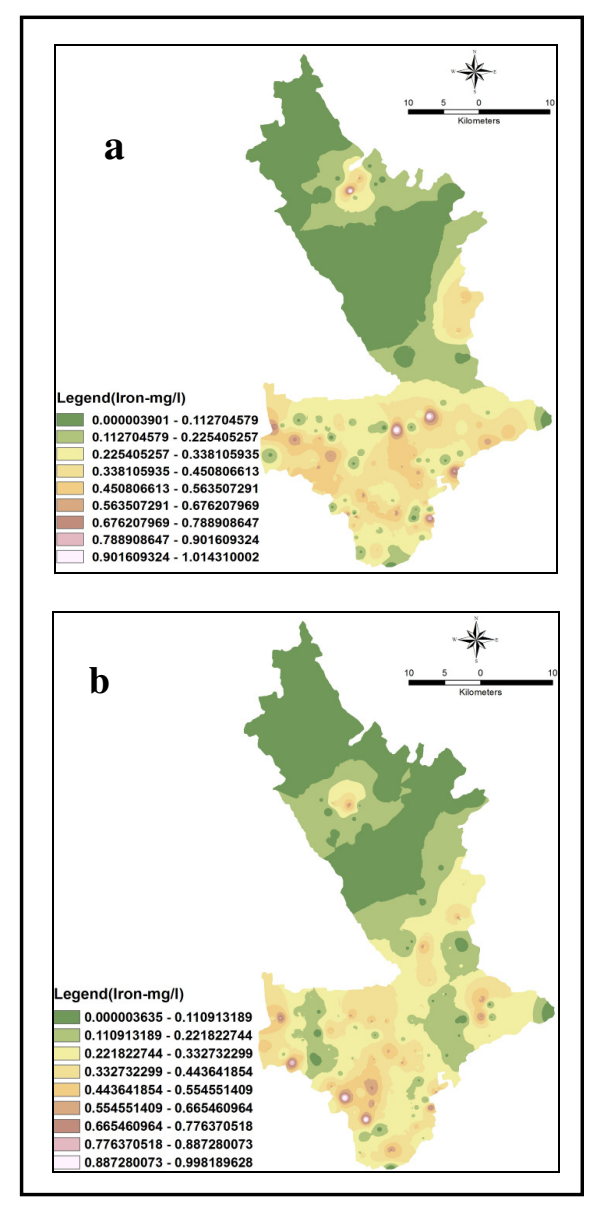

Figure 5. Spatial distribution map of Iron concentration in groundwater samples for both pre and post monsoon season showing in figure $\mathrm{a} \& \mathrm{~b}$ respectively.
This figure suggests that, 80-113 tubewells has non potable limit of iron or above the permissible limit. Non potable limit covers $21 \%$ in pre-monsoon and $34.21 \%$ in post-monsoon over the region. Spatial distribution map of Iron concentration in groundwater samples for both pre and post monsoon season shown in Figure 5.

Arsenic: The significant source of arsenic is the mobilization of arsenic from sediments to ground water. Geochemical conditions, such as $\mathrm{pH}$, oxidation-reduction, associated or competing ions, and evaporative environments, have significant effects on arsenic concentration in ground water (Hundal, et al., 2007). The research and studies indicated that sand and clay deposited by river is generally rich in iron and arsenic and the highest arsenic concentration zone exits below 40 meters. The desirable limit covered $71 \%$ area and permissible limits covered $28 \%$ area from the total area of the region in pre-monsoon. In pre-monsoon 54 tubewells has permissible limit of the arsenic ranging 0.01-0.02 mg/l. On the otherhand, all area come under desirable limits ranging $<0.01 \mathrm{mg} / \mathrm{l}$. The study found no alarming situation in the region for arsenic concentraion in groundwater.

\section{Integrated Groundwater Quality Map:}

In this present study, all the individual parameter-wise water quality spatially interpolated layers have to be integrated for generating a composite ground water quality layer. Total eigth no. of water quality layers have been generated and according to the drinking water classes (BIS), these maps can be classified into three major classes like desirable, acceptable / permissible and non-potable classes for both pre and post monsoon season. All the classes have been given code as 1, 2, or 3 for desirable, acceptable / permissible and non-potable respectively in in GIS framework. Later combining all the water quality layers, the calculation and assignment of class value can be done using any standard GIS software by evolving a suitable statistical equation. After deriving final water quality classes dissolve the adjacent polygons with same class value. Finally the integrated ground water quality layer with three types of water quality classes have been generated with respect to pre and post monsoon season. In the integrated groundwater quality map, it can be easily diffrentiate the groundwater quality w.r.to the pre and post monsoon season for drinking water purpose (Figure 6).

\section{Conclusion:}

A procedure that integrates the traditional groundwater sampling analysis methods and GIS capabilities combined with conditional combining techniques was adapted in order to locate the suitable areas at the groundwater aquifer for drinking purposes. All analytical results compared with BIS standards and classified as desirable, permissible and non-potable groundwater classes in both seasons. The groundwater at areas such as Saheri, Chamkaur Sahib, Sekhupur, Chalaki show high value of Iron concentration above permissible limit for both the seasons. But in some villages such as Charheri and Kotla Nihang found Iron concentration in desirable limit in premonsson season and non-potable in post-monsoon season due some some geochemical pollution. Sulphate concentraion also found higher values in pre-monsoon season near northern part of the region but in post-monsoon, the concention values come under control. The overall quality in Rupnagar district states that the drinking water quality is much deteriorated according to Indian drinking water standards but the concentration of Iron 
and sulphate are alarming for the people living in this region due to the underlying soil chemistry, geology and hydrogeology. It is therefore, heavy metal studies can be done for this region and remedies can be taken care to match the BIS standard.

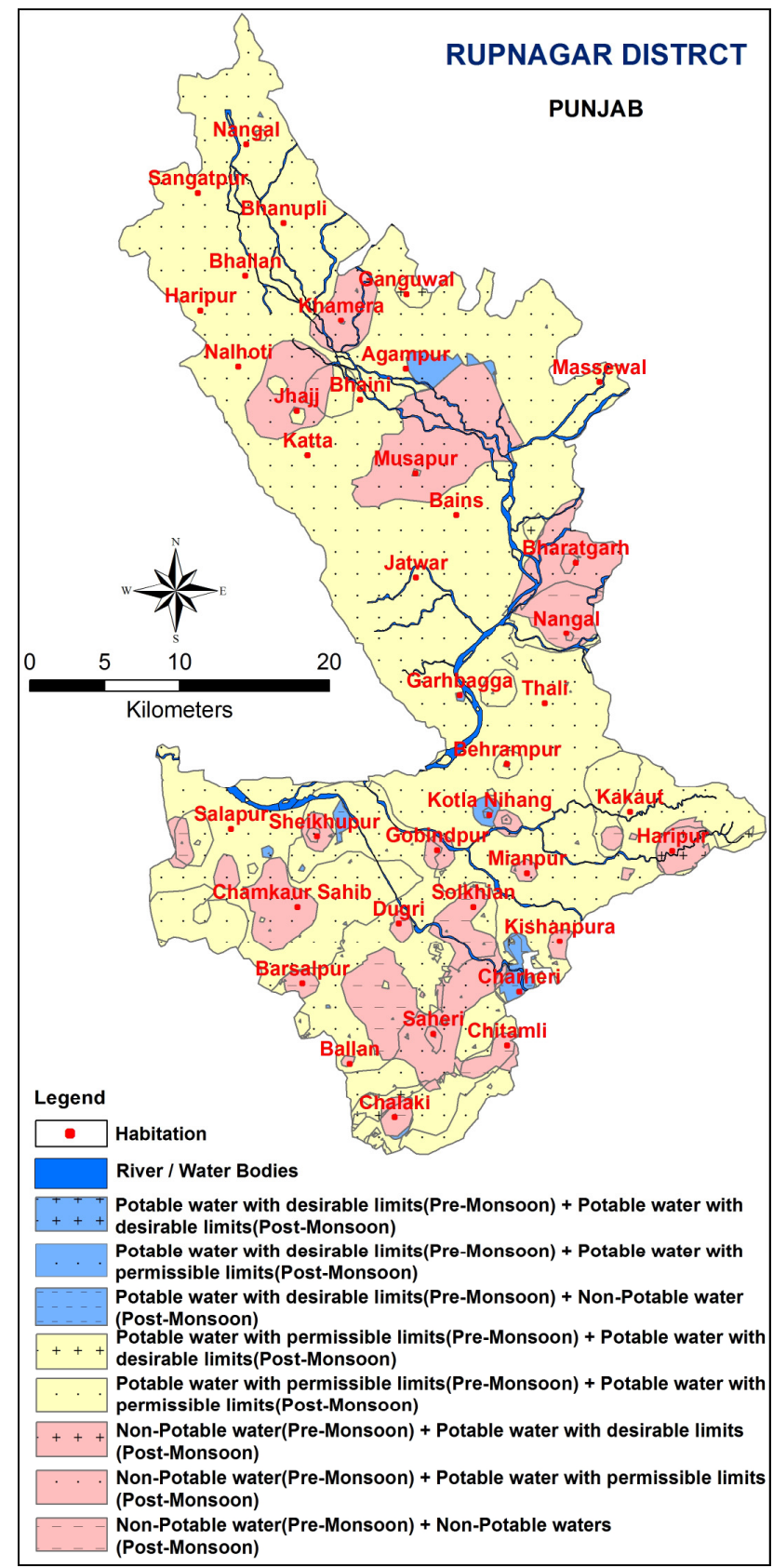

Figure 6. Integrated groundwater quality map shows the groundwater quality w.r.to the pre and post monsoon season for drinking water purpose.

The status of $\mathrm{pH}$, Total Hardness, Alkalinity, TDS and minerals like Arsenic and Fluoride concentration observed somehow manages the drinking water standards in both seasons. This type of approach needs to include management of land use, wastewater and solid waste disposal, monitoring groundwater contamination, and regulating groundwater use. Without immediate action, water that is currently unfit for human consumption will not be suitable for other uses. These maps are very much needful for human being to expand awareness among the people to maintain the Cleanness of water at their highest quality and purity levels to achieve a healthy life. Hence, it is suggested to monitor groundwater quality on a periodic basis and plan to be worked out to prevent further deterioration of water quality.

\section{References:}

Atapour, H., 2012. Geochemical baseline of major anions and heavy metals in groundwater and drinking waters around the urban areas of Kerman city, southeastern Iran. Environ Earth Sci., 67(7), pp. 2063-2076.

Caroll, D., 1962. Rainwater as a chemical agent of geological processes are view. USGS water supply, 1533, pp.18-20.

CGWB, 2007. Groundwater information booklet of Ropar district Punjab, Ministry of Water Resources, Govt. of India.

David, K., Essumang, Senu J., Fianko, JR., Nyarko, BK., Adokoh, CK., Boamponsem, L., 2011. Groundwater quality assessment: a physicochemical properties of drinking water in a rural setting of developing countries. Can J Sci Ind Res, 2, pp. 102-126.

Hundal, H. S., Kumar, R., Singh, K., Singh, D., 2007. Occurrence and geochemistry of arsenic in groundwater of Punjab, Northwest India. Communications in Soil Science and Plant Analysis, 38, pp. 2257-2277.

Khadri, Chaitanya Pande SFR., Moharir, K., 2013. Groundwater quality mapping of PTU watershed in Akola district of Maharashtra India using geographic information system techniques. Int J Sci Eng Res, 4(9), September.

Kumari, R., Singh, CK., Datta, PS., Singh, N., Mukherjee, S., 2012. Geochemical modelling, ionic ratio and GIS based mapping of groundwater salinity and assessment of governing processes in Northern Gujarat, India. Environ Earth Sci. doi:10.1007/s12665-012-2067-3.

Matthess, G., 1982. The properties of groundwater. Wiley, New York.

Nas, B., Berktay, A., 2010. Groundwater quality mapping in urban groundwater using GIS. Environ Monit Assess, 160(1-4), pp. 215-227.

NRSC, 2008. Guidelines for preparation of Ground Water Quality layer, Rajiv Gandhi National Drinking Water Mission Project Manual, National Remote Sensing Centre (ISRO / Dept. of Space, Govt. of India. 30p.

Ntengwe, FW., 2006. Pollutant loads and water quality in stream of heavily populated and industrialized towns. Phys Chem Earth, 31, pp. 832-839.

Olajire, AA., Imeokparia, FE., 2001. Water quality assessment of Osun River: studies on inorganic nutrients. Environmental Monitoring Assessment, 69(1), pp. 17-28.

Singh, CK., Kumari, R., Singh, RP., Mukherjee, S., 2014. Geochemical characterization and heavy metal contamination of groundwater in Satluj River Basin. Environmental Earth Sciences, 71(1), pp. 201-216. 
Subramani, T., Elango, L., Damodarasamy, SR., 2005. Groundwater quality and its suitability for drinking and agricultural use in Chithar River Basin, Tamil Nadu, India. Environ Geol., 47, pp. 1099-1110.

Vijith, H., Satheesh, R., 2007. Geographical information system based assessment of spatiotemporal characteristics of groundwater quality of upland subwatersheds of Meenachil River, parts of Western Ghats, Kottayam District, Kerala, India. Environ Geol., 53(1), pp. 1-9.

WHO, 1996. Guidelines for drinking-water quality. 2nd ed. Vol 2: Health criteria and other supporting information. World Health Organization, Geneva.

WHO, 2004. Guidelines for drinking-water quality, world health organization (p. 515, 3rd ed.) (vol. 1) Geneva, Recommendations.

Yidana, SM., Yidana, A., 2010. Assessing water quality using water quality index and multivariate analysis. Environ Earth Sci, 59(7), pp. 1461-1473. 